\title{
Supply-Side School Improvement and the Learning Achievement of the Poorest Children in Indigenous and Rural Schools: the Case of PARE
}

\author{
Vicente Paqueo and Gladys Lopez-Acevedo*
}

\begin{abstract}
$\underline{\text { Abstract }}$
In the past, research findings indicated that most of the differences in student learning was due to socioeconomic factors and that, therefore, the effect of direct educational interventions to reduce learning inequality was very limited. However, this paper shows that learning achievement could increase through appropriately designed and reasonably well-implemented interventions. An examination of Mexico's PARE program reveals that an increase in learning achievement could be possible for rural and indigenous schools. The overall conclusion is that supply-side interventions can have substantial effects on the learning achievement of children in indigenous and rural schools in poor areas. Greater attention, however, needs to be paid to the poorest of the disadvantaged children. This positive conclusion, however, should be tempered by results of the urban sample, confirming earlier findings of the negative relationship between PARE and student learning growth.
\end{abstract}

World Bank Policy Research Working Paper 3172, December 2003

The Policy Research Working Paper Series disseminates the findings of work in progress to encourage the exchange of ideas about development issues. An objective of the series is to get the findings out quickly, even if the presentations are less than fully polished. The papers carry the names of the authors and should be cited accordingly. The findings, interpretations, and conclusions expressed in this paper are entirely those of the authors. They do not necessarily represent the view of the World Bank, its Executive Directors, or the countries they represent. Policy Research Working Papers are available online at http://econ.worldbank.org.

\footnotetext{
* Vicente Paqueo is Lead Economist, HD, and Gladys Lopez is Economist, PREM at the World Bank.
} 


\section{Introduction}

Questions have been raised about the impact of government programs on the well being of the poorest of the poor. Supply-side interventions, that seek to improve the quality of publicly provided services, have been particularly vulnerable to doubts about their effectiveness.

This case study of the effect of Programa para Abatir el Rezago Educativo (PARE) on the learning achievement of disadvantaged children seeks to contribute to the discussion of this issue. PARE is an example of a supply-side school improvement program designed to improve the learning of poor, rural and indigenous children in selected low-income provinces.

As in most developing countries, there is dearth of information regarding the impact of education programs on learning achievement, let alone their effects on the poorest of the poor children. Mexico, however, has had the foresight to collect socioeconomic and education background information among control and experimental groups of schools at the beginning and the end of the project.

Previous analyses showed that on the whole PARE was cost effective, particularly among indigenous and rural children. No analysis, however, has been undertaken to measure and compare the learning effects of this education compensatory program on the poorest and less poor children. This study, therefore, explores the differential effects of PARE on the learning achievement between the poorest and less poor children in indigenous and rural schools.

The paper is divided as follows. The next two sections briefly describe the PARE Project and the above-mentioned database. Section 4 then discusses the main hypothesis of the study in the context of the learning achievement literature and lays the bases for the specification of the model to be tested in the next section. The final section discusses the main findings and conclusion of the study.

\section{The PARE Project}

During the 90's, the Mexican government introduced compensatory education programs as a key element in reducing inequality in the education system by channeling more resources to the poorest states. Since 1992, the programs have broadened their coverage and strengthened their institutional capacity building.

PARE was undertaken in 1992-1997. The objective of the program was to assist the Government of Mexico in improving the quality and efficiency of primary education, focusing on four Mexican states (Oaxaca, Guerrero, Chiapas and Hidalgo) with the highest incidence of poverty and low education indicators. These objective, considered as being of the highest priority with the Government's Education Modernization Program, would be achieved through; (i) reducing the high repetition and dropout rates;

(ii) raising the level of cognitive achievement of children, and (iii) strengthening management of the 
primary education system, including program design and implementation, monitoring and evaluation system.

The PARE states comprised $13.2 \%$ of the total Mexican population but a much higher proportion of those living in poverty. Viewed together, these states had an average primary school completion rate of $39 \%$, with dropout averaging $9.9 \%$. Reported repetition rates averaged $14.7 \%$, which has been shown to be an underestimate of the real rates.

In all four states, the educational system as in other states is predominantly public. The control of public schools, however, differed slightly. When PARE was implemented, ownership of Federal schools have not yet been turned over to the states. In Oaxaca and Hidalgo, all public primary schools were managed and operated by federal authorities through SEP's delegations, while in Chiapas and Guerrero, both federal and state systems coexisted (the latter being small and relatively concentrated around urban areas). For the whole project area, the federal system was thus predominant ( $92 \%$ of public schools) and even more so in rural areas. Indigenous schools and CONAFE community courses, in particular, were all federal schools, which were run by various entities. The Federal Government has the prerogative to provide direct support to state schools and to coordinate actions taken under both educational systems.

The project was directed towards all public (federal and state) primary schools students, teachers and supervisors in the four states. Several of PARE's interventions, however, were specifically targeted towards rural areas because in those areas the degree of poverty and the lack of family financial support and school resources are greatest.

The project had two main components: The Educational Services Improvements Component (72\% of total cost including contingencies) to improve the availability and quality of educational services for the primary school students (i.e., books, didactic materials, training of teachers, school infrastructure and distance education technologies and the Institutional Strengthening Component $(28 \%$ of total cost including contingencies) to further the efficiency of the of the primary education sector.

SEP was responsible for overall coordination and attainment of project objectives. Implementation responsibilities were shared by SEP at the central level and its state delegations. The State delegations were also responsible for supervising and monitoring the support provided under the project to state schools. There was a survey of school needs to refine the precise contents of the educational materials packages and other school needs.

In each of the states, a small Program Coordinator Unit was established and its head directly reported to the director of each state delegations. It was responsible for coordinating activities of all participants agencies and monitoring project implementation at the state level. Some of the problems faced by the compensatory programs were: (a) annual delays in budget approval for project expenses; (b) 
persistent complicated internal procedures and controls for approving budgets for specific activities; and (c) prolonged postponement of decisions regarding important studies for evaluation.

\section{Previous studies}

From its inception PARE's performance was monitored through statistical comparisons between the target, or experimental, population (schools in the states of Chiapas, Guerrero, Hidalgo and Oaxaca) and a control group formed by students in comparable schools in the state of Michoacan which falls outside the scope of the program. Special surveys were conducted yearly between 1992 and 1995. In addition, all students were given standardized achievement tests in Spanish and mathematics. PARE also provided the resources to evaluate the success of this program. To this end, two studies were conducted by two different research institutions. One study was done by the C.E.E (Centro de Estudios Educativos), which focused mainly on measuring quantitative variables regarding school inputs and the academic and socioeconomic characteristics of students, parents, community, teachers, principals and supervisors. The other study was undertaken by the D.I.E (Departamento de Investigaciones Educativas), which examine qualitative variables. The database was developed to evaluate the effects of PARE on student achievement.

During program implementation, several standardized tests on Mathematics and Spanish were given to the students in three consecutive years, when they were in fourth, fifth and sixth grades. The test scores provide analysts outcome indicators and allow estimation of the value-added of PARE.

Two previous Bank analyses of these data reveal that PARE has a significant impact on student learning. Table 1 below, which has been drawn from the PAREIB Project Appraisal Document ${ }^{1}$, shows before and after comparison of Spanish test scores of the control and experimental groups of students in indigenous, rural (regular) and urban schools. Table 2 shows the per student intervention costs. Table 1 reveals that in indigenous and rural schools where PARE was fully implemented as designed, the project was able to increase by 42.3 percent the Spanish test scores of indigenous students, and by 16.5 percent the corresponding scores of students in regular rural schools. With the cost of these improvements estimated at about 38.1 and 24.2 percent of routine expenditure per student, respectively, the elasticity of student learning achievement in Spanish with respect to cost would appear to be about 1.11 and 0.66 in that order.

\footnotetext{
${ }^{1}$ PAREI PAD
} 
Table 1. The Effect of PARE Intervention on Spanish Test Score

\begin{tabular}{lcccccc}
\hline & \multicolumn{2}{c}{ Before (1992) } & \multicolumn{2}{c}{ After (1994) } & \multicolumn{2}{c}{ Difference } \\
\hline & Students & $\begin{array}{c}\text { Average test } \\
\text { Score }\end{array}$ & Students & $\begin{array}{c}\text { Average test } \\
\text { score }\end{array}$ & Total & Percentage \\
\hline Native & & & & & & \\
Experimental & 564 & 14.6 & 356 & 29.1 & 13.9 & 95.3 \\
Control & 205 & 23.2 & 125 & 26.8 & 4.1 & 17.7 \\
Total - t/test & 769 & 16.9 & 481 & 28.5 & 11.4 & 67.3 \\
& & & & & & \\
Rural & & & & & & \\
Experimental & 645 & 20.7 & 421 & 32.9 & 11.6 & 56.0 \\
Control & 208 & 20.1 & 128 & 29.7 & 8.2 & 40.6 \\
Total - t/test & 853 & 20.5 & 549 & 32.1 & 10.8 & 52.5 \\
& & & & & & \\
Urban & & & & & & \\
Experimental & 337 & 26.9 & 238 & 39.7 & 12.0 & 44.5 \\
Control & 361 & 26.9 & 221 & 44.3 & 15.9 & 59.3 \\
Total - t/test & 698 & 26.9 & 459 & 41.9 & 13.9 & 51.6 \\
Source: PARE Survey & & & & & & \\
\hline
\end{tabular}


Table 2. Per pupil costs PARE program, 1994

\begin{tabular}{|c|c|c|c|c|c|c|c|c|c|c|}
\hline & $\begin{array}{c}\text { Bilingual } \\
\text { texts }\end{array}$ & Library & Stores & Training & Infrastructure & $\begin{array}{c}\text { Supplementary } \\
\text { compesation } \\
\text { for teachers }\end{array}$ & $\begin{array}{c}\text { Audovisual } \\
\text { equipment and } \\
\text { materials }\end{array}$ & $\begin{array}{c}\text { School } \\
\text { supervision }\end{array}$ & $\begin{array}{l}\text { Didactic } \\
\text { materials }\end{array}$ & Total \\
\hline \multicolumn{11}{|c|}{ Per pupil expenditure - Indigenous schools } \\
\hline Chiapas & 21.5 & 3.5 & 2.0 & 45.6 & 215.2 & 0.0 & 111.3 & 47.0 & 159.5 & 605.7 \\
\hline Guerrero & 20.2 & 3.2 & 4.1 & 50.1 & 282.1 & 45.8 & 101.1 & 103.2 & 139.4 & 749.1 \\
\hline Hidalgo & 25.2 & 7.4 & 3.3 & 62.0 & 635.2 & 123.4 & 78.3 & 82.3 & 109.8 & 1126.7 \\
\hline Oaxaca & 9.2 & 4.6 & 3.5 & 50.3 & 279.7 & 52.8 & 139.3 & 29.2 & 55.6 & 624.1 \\
\hline $\begin{array}{l}\text { Average } \\
\text { cost }\end{array}$ & 19.0 & 4.7 & 3.2 & 52.0 & 353.1 & 55.5 & 107.5 & 65.4 & 116.1 & 776.4 \\
\hline \multirow{2}{*}{\multicolumn{11}{|c|}{ Per pupil expenditure - Rural schools }} \\
\hline & & & & & & & & & & \\
\hline Chiapas & 0.0 & 7.3 & 3.2 & 32.7 & 32.6 & 21.2 & 136.4 & 39.4 & 65.4 & 338.1 \\
\hline Guerrero & 0.0 & 4.8 & 6.4 & 40.8 & 333.0 & 4.0 & 97.9 & 139.9 & 137.5 & 764.2 \\
\hline Hidalgo & 0.0 & 10.6 & 4.1 & 58.7 & 302.4 & 16.8 & 93.6 & 62.4 & 88.2 & 636.8 \\
\hline Oaxaca & 0.0 & 6.1 & 4.4 & 42.9 & 0.0 & 0.0 & 94.2 & 46.5 & 35.7 & 229.7 \\
\hline $\begin{array}{l}\text { Average } \\
\text { cost }\end{array}$ & 0.0 & 7.2 & 4.5 & 43.8 & 167.0 & 10.5 & 105.5 & 72.1 & 81.7 & 492.2 \\
\hline \multicolumn{11}{|c|}{ Per pupil expenditure - Urban schools } \\
\hline Chiapas & 0.0 & 5.0 & 4.0 & 48.1 & 0.0 & 0.0 & ---- & 20.1 & 133.5 & 210.7 \\
\hline Guerrero & 0.0 & 1.6 & 1.0 & 27.3 & 0.0 & 0.0 & ---- & 9.8 & 23.1 & 62.8 \\
\hline Hidalgo & 0.0 & 1.4 & 0.6 & 28.3 & 0.0 & 0.0 & ---- & 13.4 & 7.3 & 51.0 \\
\hline Oaxaca & 0.0 & 0.8 & 0.3 & 16.4 & 0.0 & 0.0 & ---- & 5.8 & 0.6 & 23.8 \\
\hline $\begin{array}{l}\text { Average } \\
\text { cost }\end{array}$ & 0.0 & 2.2 & 1.5 & 30.0 & 0.0 & 0.0 & ---- & 12.3 & 41.1 & 87.1 \\
\hline
\end{tabular}


A surprising finding is that in urban schools improvement in the learning achievement of students appears lower for the experimental vis-à-vis control group. It is difficult to explain this result. It is possible that the selection of the control group was not properly done. Having said this, we note that the PARE program was not well implemented among the urban schools. Delivery of planned interventions were either not delivered or delayed. A further investigation of this result is needed. Lessons could perhaps be learned in understanding how a well designed project could end up hurting children's education, if it is poorly implemented. It might be that delays and non-delivery of planned inputs created confusion, de-motivated schools and generated changes in schools that became harmful without timely delivery of complementary assistance and resources.

In a recent education sector study ${ }^{2,}$ a two-stage least squares regression model, in which learning achievement and the monetary value of PARE assistance to schools were treated as endogenous, was estimated on the combined indigenous, rural and urban samples ${ }^{3 .}$ The model treats the amount of assistance received by schools to be dependent on the school's learning achievement score, on the assumption that the program has systematically given more assistance to more disadvantaged schools. The analysis reveals that holding other things constant, there is a significant positive correlation between learning achievement and the monetary value of PARE assistance (Table 2).

\footnotetext{
${ }^{2}$ World Bank, Mexico: Advancing Educational Equity and Productivity in the Context of Decentralization), November 1998 (Processed)

${ }^{3}$ The dummy variable representing whether or not a student is in the experimental schools was used to identify the learning achievement equation.
} 
Table 2. Determinants of Sixth Grade Spanish Test Score:

PARE, 1994

\begin{tabular}{|c|c|c|}
\hline & $\begin{array}{l}\text { Regression } \\
\text { Co-efficient }\end{array}$ & t-value \\
\hline \multicolumn{3}{|l|}{ Dependent: } \\
\hline \multicolumn{3}{|l|}{ Independent Variables: } \\
\hline Child's past Academic Record & -.139 & -1.68 \\
\hline Per student cost of PARE & .005 & 2.08 \\
\hline Assistance & & \\
\hline Score in $4^{\text {th }}$ Grade & .251 & 9.91 \\
\hline Family’s Cultural Capital & .105 & 3.95 \\
\hline Teacher's Performance $5^{\text {th }}$ grade & .095 & 2.39 \\
\hline Teacher's Performance $6^{\text {th }}$ grade & .126 & 2.93 \\
\hline Director's Quality & .092 & 2.20 \\
\hline Supervision Quality & .047 & 2.76 \\
\hline Parent's Participation & -.062 & -2.80 \\
\hline DUMMY for Rural & -8.882 & -9.08 \\
\hline DUMMY for Indigenous & -12.422 & -8.85 \\
\hline (Constant) & 23.079 & 4.72 \\
\hline Adjusted R square & & .26 \\
\hline $\mathrm{N}=2114$ & & \\
\hline Estimation method & & \\
\hline Squares & & \\
\hline
\end{tabular}

This analysis indicates that, learning achievement elasticity with the respect to cost of intervention stood at about 0.33 . This is lower than the previous estimate since the second analysis allowed for the many imperfections in implementation to be factored in, particularly the urban implementation problems. Still, the learning effect relative to cost for the combined indigenous, rural and urban samples remains substantial.

This analysis held constant a number of school and student background characteristics. It is worth mentioning that the quality of school principals, teachers, and supervisors appears to be a significant determinant of Spanish test score. An unexpected result is that parental participation appears to have significantly negative correlation. This probably reflects simultaneity bias, reflecting the fact that parents tend to be more active when children are not doing well in school. A recent U.S. study shows that parental participation takes on the expected positive effect when it is treated as an endogenous variable. ${ }^{4}$

\section{Hypothesis}

\footnotetext{
${ }^{4}$ Robert McMillan, Parental Pressure and Competition: An Empirical Analysis of the Determinants of Public School Quality, January 10, 1999 (Processed).
} 
The main hypothesis of this paper is that targeting school improvement programs on poor areas, even when effective, does not necessarily translate in significant improvements in the learning achievement of the poorest of the poor children. In general, one would expect that without paying special attention to them, they are likely to benefit less from these school improvement programs for two reasons.

First, it is possible that due to political economy considerations, schools with disproportionately more children from the poorest families might be getting relatively less additional resources and attention from school improvement program. Second, it is also likely that children from the very poor are unable to fully take advantage of the new opportunities made available from school quality improvements. The productivity of the additional school inputs among the poorest students in regard to learning might have already been compromised by malnutrition and lack of brain stimulation when they were at a vulnerable stage of their young life.

In view of this hypothesis and earlier findings, we estimate student test score in Spanish of sixth grade student (i) as a linear function of the following independent variables: the child's age, his test score at fourth grade, mother's education, the quality of school directors, teachers and supervisors, distance to school from the state capital to the locality and a dummy variable representing whether the student is in an "experimental" or "control" school. This dummy variable is interacted with another dummy variable indicating socioeconomic status to separate the effect of PARE intervention between poor (POB) and less poor children. That is,

$$
\begin{gathered}
\text { ESPANOL6 (i) }=a+b X(i)+\operatorname{cPARE}(i) * \text { POB (i) }+\operatorname{dPARE}(\mathrm{i})(1-\mathrm{POB}(\mathrm{i})) \\
+\operatorname{eESPANOL} 4(\mathrm{i})+\mathrm{U}(\mathrm{i})
\end{gathered}
$$

where

ESPANOL6 (i) $=$ the Spanish test score of a sixth grade student $i$

ESPANOL4 (i) $=$ the Spanish test score of $i$ at fourth grade

$\operatorname{PARE}(\mathrm{i})=1$ if $\mathrm{i}$ is a student in an experimental school; 0 , otherwise (control)

POB (i) $=1$ if the student comes from the lower half of the socioeconomic status scale; 0 , otherwise

$\mathrm{X}(\mathrm{i})=$ other socioeconomic and school background variables (see below)

$\mathrm{U}(\mathrm{i})=$ error term

The hypothesis is that $\mathrm{c}<\mathrm{d}$. The above equation is estimated below by ordinary least squares.

\section{Sample characteristics}

Table 3 shows the distribution of students by school type in the sample. Our analysis will focus on schools located in rural and native communities, the two most disadvantaged groups in the population with the lowest educational attainment, poorest test performance and highest incidence of school 
desertion. At the margin, the supplemental actions provided by the program should have the greatest impact amongst this population.

Table 3. Distribution of Students by School Type and State

\begin{tabular}{|l|r|r|r|r|r|r|r|}
\hline & Chiapas & Guerrero & Hidalgo & Oaxaca & $\begin{array}{c}\text { Sub-total: } \\
\text { Experimen } \\
\text { tal }\end{array}$ & $\begin{array}{c}\text { Michoacan } \\
\text { : Control }\end{array}$ & Total \\
\hline Urban & 398 & 107 & 257 & 357 & 1,119 & 361 & 1,480 \\
\hline Rural & 200 & 202 & 175 & 239 & 816 & 208 & 1,024 \\
\hline Native & 197 & 114 & 122 & 259 & 692 & 205 & 897 \\
\hline Community & 19 & 11 & 29 & 59 & 118 & 27 & 145 \\
\hline Total & 814 & 434 & 583 & 914 & 2,745 & 801 & 3,546 \\
\hline \multicolumn{2}{l}{ Source: PARE's database. } & & & & & \\
\hline
\end{tabular}

The sample consists of students from 198 schools randomly chosen from four different types of schools from five different states (Table 4).

Table 4. Sample of Schools by Type and State

\begin{tabular}{|l|c|c|c|c|c|}
\hline \multicolumn{1}{|c|}{ State } & Urban & Rural & Native & CONAFE & Total \\
\hline Chiapas & 6 & 13 & 14 & 5 & 38 \\
\hline Guerrero & 4 & 14 & 12 & 4 & 34 \\
\hline Hidalgo & 3 & 11 & 12 & 8 & 34 \\
\hline Oaxaca & 7 & 17 & 15 & 12 & 51 \\
\hline Michoacan & 7 & 15 & 10 & 9 & 41 \\
\hline Total & 27 & 71 & 64 & 44 & 198 \\
\hline \multicolumn{2}{l|}{ Source: PARE's database. } & & & & \\
\hline & & & & & \\
\hline
\end{tabular}

The sample means and standard deviations of selected variables, which are defined operationally in the annex, are presented in Table 4 below by stratum. It clearly shows how disadvantaged the children in indigenous and rural school are in terms of their learning achievement, socioeconomic background (e.g. mother's education); and the quality of the their teachers and school directors. 
Table 5 Means and Standard Deviations of Selected Variables

\begin{tabular}{|c|c|c|c|c|c|c|c|c|}
\hline \multirow{2}{*}{\begin{tabular}{|l} 
ALL SAMPLE \\
Variable \\
\end{tabular}} & \multicolumn{2}{|l|}{ All } & \multicolumn{2}{|l|}{$\begin{array}{l}\text { INDIGE- } \\
\text { NOUS }\end{array}$} & \multicolumn{2}{|l|}{ RURAL } & \multicolumn{2}{|l|}{ URBAN } \\
\hline & Mean & Std Dev & Mean & Std Dev & Mean & Std Dev & Mean & Std Dev \\
\hline $6^{\text {th }}$ grade Spanish test score (ESPANOL6) & 36.11 & 13.3 & 28.65 & 10.47 & 32.06 & 10.61 & 42.62 & 13.11 \\
\hline Spanish test score at $4^{\text {th }}$ grade (ESPANOL4) & 22.68 & 11.5 & 17.39 & 11.78 & 20.68 & 10.58 & 27.28 & 10.09 \\
\hline Child's age (EDAD_AL) & 9.4 & 1.02 & 9.78 & 1.28 & 9.4 & 0.86 & 9.13 & 0.8 \\
\hline Mother's education (MADESC_1) & 4.27 & 3.83 & 2.11 & 2.41 & 3.16 & 2.63 & 6.47 & 4.17 \\
\hline Performance of $5^{\text {th }}$ grade teacher (DESEMP6) & 51.86 & 7.61 & 48.62 & 4.81 & 50.15 & 9.7 & 55.01 & 5.96 \\
\hline Performance of $6^{\text {th }}$ grade teacher (DESEMP6) & 42.83 & 5.42 & 41.89 & 5.73 & 42.28 & 5.4 & 43.78 & 5.08 \\
\hline School director's quality (DC_ACA_1) & 52.27 & 7.05 & 50.25 & 5.84 & 49.04 & 7.4 & 55.74 & 5.82 \\
\hline Supervision quality (CALI_S_1) & 63.69 & 18.35 & 61.71 & 22.37 & 64.26 & 16.83 & 64.5 & 16.48 \\
\hline Parental school participation (APF6_1) & 35.34 & 12.23 & 34.46 & 11.81 & 32.9 & 11.82 & 37.56 & 12.37 \\
\hline Distance to the state capital (DISTANT) & 1.85 & 0.8 & 1.99 & 0.82 & 1.95 & 0.81 & 1.7 & 0.75 \\
\hline & $\mathrm{N}=3401$ & & $\mathrm{~N}=897$ & & $\mathrm{~N}=1024$ & & $\mathrm{~N}=1480$ & \\
\hline
\end{tabular}




\section{Findings and conclusions}

The regression results are presented in Table 6. They suggest the following conclusions regarding the impact of PARE on learning achievement:

(a) The PARE intervention has not significantly improved the test score of the poorest children of indigenous schools; in contrast, it has increased considerably the learning achievement of the less poor.

(b). In the sample of rural (regular) schools, PARE improved the learning achievement of both the poorest and less poor children, although the former benefited slightly less than the latter.

(c). Taking both indigenous and regular rural schools together, it would appear that the poorest children increased their Spanish test scores by only a half of that achieved by less poor children. It is also evident that staff quality/performance is a significant determinant of student learning achievement.

The overall conclusion is that supply-side interventions can have substantial effects on the learning achievement of children in indigenous and rural schools in poor areas. Greater attention, however, needs to be paid to the poorest of the disadvantaged children. This positive conclusion, however, should be tempered by results of the urban sample, confirming earlier findings mentioned above about the negative relationship between PARE and student learning growth. The urban regression equation reveals that PARE intervention is negatively associated with Spanish test scores for both groups of children. Furthermore, the PARE coefficient (in absolute value) is larger for the poorest than less poor students. It is difficult to explain this negative correlation. This could be due to the disruptive effects of the interventions, which PARE introduced in the selected urban schools only during its last year. For example, introduction of new teaching materials and pulling teachers out of the classroom for training could have disruptive effects. But other possible explanations previously mentioned exist. Additional research is needed to understand the meaning of this finding. 
Table 6. Regression Results

By strata

Depndent Variable ESPANOL6 $\left(6^{\text {th }}\right.$ grade Spanish test score.)

\begin{tabular}{|c|c|c|c|c|c|c|c|c|}
\hline \multirow[b]{2}{*}{ Variable } & \multicolumn{2}{|l|}{ Indigenous } & \multicolumn{2}{|l|}{ Rural } & \multicolumn{2}{|l|}{ Urban } & \multicolumn{2}{|c|}{ Indigenous/Rural } \\
\hline & Coefficient & $T$ & Coefficient & $\mathbf{T}$ & Coefficient & $\mathbf{T}$ & Coefficient & $T$ \\
\hline $\begin{array}{l}\text { Spanish test score at } 4^{\text {th }} \text { grade } \\
\text { (ESPANOL4) }\end{array}$ & 0.091 & 2.27 & 0.153 & 3.80 & 0.386 & 9.85 & 0.150 & 5.44 \\
\hline Child's age (EDAD_AL) & 0.404 & 0.99 & -0.215 & -0.44 & 0.079 & 0.15 & 0.005 & 0.02 \\
\hline $\begin{array}{l}\text { Mother's education } \\
\text { (MADESC_1) }\end{array}$ & 0.380 & 2.06 & 0.125 & 0.79 & 0.599 & 6.04 & 0.267 & 2.26 \\
\hline $\begin{array}{l}\text { Performance of } 5^{\text {th }} \text { grade } \\
\text { teacher (DESEMP5) }\end{array}$ & 0.035 & 0.38 & 0.068 & 1.78 & 0.009 & 0.15 & 0.077 & 2.21 \\
\hline $\begin{array}{l}\text { Performance of } 6^{\text {th }} \text { grade } \\
\text { teacher (DESEMP6) }\end{array}$ & 0.062 & 0.94 & 0.004 & 0.06 & 0.093 & 1.42 & 0.053 & 1.16 \\
\hline $\begin{array}{l}\text { School director's quality } \\
\text { (DC_ACA_1) }\end{array}$ & 0.028 & 0.37 & 0.310 & 5.45 & -0.254 & -3.68 & 0.209 & 4.63 \\
\hline $\begin{array}{l}\text { Supervision quality } \\
\text { (CALI_S_1) }\end{array}$ & 0.076 & 3.10 & 0.018 & 0.77 & 0.063 & 2.49 & 0.039 & 2.36 \\
\hline $\begin{array}{l}\text { State capital distance } \\
\text { (DISTANT) }\end{array}$ & -1.596 & -2.63 & -1.001 & -1.85 & -1.414 & -2.65 & -0.853 & -2.15 \\
\hline PARE *POB & 1.478 & 1.15 & 3.267 & 3.05 & -5.873 & -3.93 & 2.972 & 3.65 \\
\hline PARE*(1-POB) & 8.538 & 4.83 & 4.245 & 3.41 & -3.453 & -3.54 & 5.945 & 5.96 \\
\hline Constant & 13.113 & 1.68 & 9.511 & 1.54 & 37.705 & 4.33 & 6.734 & 1.51 \\
\hline F & 60.19 & & 70.31 & & 220.21 & & 120.31 & \\
\hline Sig. F & 0.00 & & 0.00 & & 0.00 & & 0.00 & \\
\hline Adjusted R Sqared & 0.09 & & 0.09 & & 0.17 & & 0.09 & \\
\hline
\end{tabular}


Annex Table: Definition of Variables

\begin{tabular}{|c|c|c|}
\hline DESCRIPTION & CONSTRUCTION & SCALE \\
\hline $\begin{array}{l}\text { DEPENDENT VARIABLE }= \\
\text { ESPANOL 6: Scores obtained in the } \\
\text { exam of Spanish in } 6^{\text {th }} \text { grade. }\end{array}$ & $\begin{array}{l}\text { Scores. The exam has six parts, reading } \\
\text { comprehension, use of graphics, writing, } \\
\text { language interpretation, literature and writing } \\
\text { expression. The grade is given by the } \\
\text { percentages of correct answers. }\end{array}$ & $0-100$ \\
\hline $\begin{array}{l}\text { INDEPENDENT VARIABLES } \\
\text { ESPANOL 4: Scores obtained in the } \\
\text { exam of Spanish in } 4^{\text {th }} \text { grade. }\end{array}$ & $\begin{array}{l}\text { Scores. The exam has six parts, reading } \\
\text { comprehension, use of graphics, writing, } \\
\text { language interpretation, literature and writing } \\
\text { expression. The grade is given by the } \\
\text { percentages of correct answers. }\end{array}$ & $0-100$ \\
\hline $\begin{array}{l}\text { CC_FAM_1: Quantitative indicator } \\
\text { of family's cultural capital. }\end{array}$ & $\begin{array}{l}\text { Includes average parents' schooling, lecture } \\
\text { habits, television and radio programs and } \\
\text { number of books in the house. }\end{array}$ & $0-100$ \\
\hline $\begin{array}{l}\text { DESEMP 5: Quantitative indicator } \\
\text { of the teacher performance in } 5^{\text {th }} \\
\text { grade. }\end{array}$ & $\begin{array}{l}\text { Academic considerations in the improvement } \\
\text { of quality of education such as school } \\
\text { objectives, teacher's practices in evaluation, } \\
\text { attendance, etc. }\end{array}$ & $0-100$ \\
\hline $\begin{array}{l}\text { DESEMP 6: Quantitative indicator } \\
\text { of the teacher performance in } 6^{\text {th }} \\
\text { grade. }\end{array}$ & $\begin{array}{l}\text { Academic considerations in the improvement } \\
\text { of quality of education such as school } \\
\text { objectives, teacher's practices in evaluation, } \\
\text { attendance, etc. }\end{array}$ & $0-100$ \\
\hline $\begin{array}{l}\text { DC_ACA_1: Quantitative indicator } \\
\text { of director's quality. }\end{array}$ & $\begin{array}{l}\text { Favorable conditions for academic activities, } \\
\text { teaching and learning processes. Directors' } \\
\text { qualifications and actualization. Distribution of } \\
\text { students in the classrooms. }\end{array}$ & $0-100$ \\
\hline $\begin{array}{l}\text { CALI_S_1: Quantitative indicator of } \\
\text { supervision's quality. }\end{array}$ & $\begin{array}{l}\text { Includes annual frequency of visits, duration, } \\
\text { occupations of interviewed people and themes } \\
\text { discussed. }\end{array}$ & $0-100$ \\
\hline $\begin{array}{l}\text { APF6_1: Quantitative indicator of } \\
\text { parents' participation in the school } \\
\text { process. }\end{array}$ & $\begin{array}{l}\text { This indicator weighs the attitudes of parents } \\
\text { with respect to teachers' attendance, parents' } \\
\text { participation in school activities and relevance } \\
\text { of parents associations in the school. }\end{array}$ & $0-100$ \\
\hline PARE: Dummy variable & $\begin{array}{l}\text { This dummy variable allows us to control for } \\
\text { the schools under PARE and out of PARE. If } \\
\text { PARE }=1 \text { the school is under PARE, if PARE } \\
=0 \text { the school is out of the program. }\end{array}$ & $0 \& 1$ \\
\hline POB: Dummy variable & $\begin{array}{l}\text { The Dummy POB defines those children with } \\
\text { family assets below the mean. }\end{array}$ & $0 \& 1$ \\
\hline DISTANT & $\begin{array}{l}\text { This indicator is the distance from the locality } \\
\text { to the state capital. }\end{array}$ & $0-100$ \\
\hline
\end{tabular}




\section{References}

CENTRO DE ESTUDIOS EDUCATIVOS (C.E.E.), Evaluación del Impacto y Efectividad de Costos para Abatir el Rezago Educativo (PARE), Informe Ejecutivo, México, D. F., 1994.

CENTRO DE ESTUDIOS EDUCATIVOS (C.E.E.), Determinación del Impacto del PARE en el Aprovechamiento y la Retención Escolares, Tercer Informe, Tomo IV, México, D. F., 1996.

CENTRO DE ESTUDIOS EDUCATIVOS (C.E.E.), Impacto y Eficiencia del Programa para Abatir el Rezago Educativo (P.A.R.E.), Tercer Informe, Tomo IV, México, D. F., 1995.

CENTRO DE ESTUdios EDUCATIVOS (C.E.E.), Anexo Metodologico, Tercer Informe, México, D. F., 1996.

Fuller, Bruce and Prema Clarke (1994), Raising School Effects While Ignoring Culture? Local Conditions and the Influence of Classroom Tools, Rules, and Pedagogy, Review of Educational Research, 64(1): 119-157.

Hanushek, Eric A., (1995), Interpreting Recent Research on Schooling in Developing Countries, The World Bank Research Observer, Vol. 10, no. 2, August.

Lopez-Acevedo, Gladys (1997) Learning Achievement and School Cost Effectiveness in Mexico: The case of the Pare Program", Working Policy Research Paper, The World Bank.

Ontiveros, J., Manuel, The Education Production Function: Simultaneous Interaction Between Students, Teachers and Bureaucrats, Ph.D. Thesis, Department of Economics, University of Houston, 1997.

Secretaria de Educación Publica (SEP), PARE, Anexo II, Informe de Conclusión (1992-1996), Mexico, D. F., 1997. 